magnetic surveys. Facilities are available for testing and calibrating these instruments and also for measuring some of the relevant physical properties of rocks and minerals. In the students' laboratory model experiments, simulating field conditions, have been developed to illustrate many of the principles employed in geophysical prospecting. A main laboratory and a number of small ones are devoted to research, and a workshop affords facilities for the construction and development of special equipment.

Current research in geophysics includes gravitymeter surveys along the margin of a gabbro mass near Insch in Scotland, and the development of an automatic method of computing the gravitational effects of various types of geological bodies. Studies of Tertiary igneous rocks in Mull and North Wales have indicated that during their extrusion or intrusion many of these rocks were magnetized in a direction opposite to that of the Earth's present field. While any theory of the Earth's magnetism must account for this adverse magnetism, possibly by invoking a reversal of the Earth's field in the geological past, the results obtained in these academic studies have an obvious bearing on the geological interpretation of magnetic surveys for mineral deposits. An attempt is now being made to use the techniques of palæomagnetism for studying the physical conditions which operated during the emplacement of granites and the injection of dykes.

On the instrumental side a flux-gate mag netometer (of the type used in aeromagnetic surveying) is being modified for use at sea, to be towed behind a ship; with this instrument it is hoped soon to make magnetic measurements in the North Atlantic. Development of a novel type of magnetometer based on nuclear magnetic resonance is expected to result in the speeding up of magnetic surveys on land, the instrument consisting essentially of a bottle of water, an electromagnet and a detector coil to measure the frequency of proton precession.

Seismic research is directed towards the production of simpler and more reproducible shocks, using an electromechanical device. Investigations, particularly of frequency attenuation and phase changes, are being continued and the new technique should prove valuable in helping to decipher shallow geological structures. Promising results have attended the evolution of an induced polarization method of locat. ing good conducting ore-bodies enveloped by an electrolyte, and equipment is now being constructed for field-trials over known metalliferous deposits.

\title{
OBITUARIES
}

\section{Prof. S. R. K. Glanville, F.B.A.}

Stephen Ranulph Kingdon Glanville, Provost of King's College, Cambridge, and Herbert Thompson professor of Egyptology in the University, died, very suddenly, on the morning of April 26, his fifty-sixth birthday. The news of his death came as a great shock, not only to his professional colleagues, but also to men and women in many countries; for there were few who knew him who did not come to rely on him for friendship and sympathy.

Glanville was the eldest son of Stephen James Glanville and was born in Westminster in 1900. He was educated at Marlborough and at Lincoln College, Oxford, where he was a modern history scholar. He graduated in Literæe Humaniores in 1922. Chance largely led him to accept a post as an English teacher in the Egyptian Delta town of Mansūrah. Once there, he fell in love with the country and its people, and set himself to study them. He joined the Egypt Exploration Society's excavations at Tell-el-Amarneh in the season of 1923, the beginning of his long record of devoted service to the Society as a field-worker, and as member and chairman of committee. In 1924, he was appointed an assistant keeper in the Department of Egyptian and Assyrian Antiquities in the British Museum, where he remained until 1933. $\mathrm{He}$ returned, however, to Egypt to work at his beloved Tell-el-Amarneh in 1925, and at Armant in 1928, and contributed to the publications on both sites. He held the Laycock Studentship of Egyptology at Worcester College, Oxford, during 1929-35.

At the British Museum, the major outstanding task of the Department was the publication of its demotic papyri. Demotic is a cursive script in which the Egyptians wrote their documents from the seventh century B.C. until the fourth century A.D.; and in 1924 there were comparatively few aids for its study. Inspired by Sir Herbert Thompson, who became his teacher, benefactor and friend, Glanville undertook this task and did pioneer work. His "Catalogue of the Demotic Papyri in the British Museum, Vol. 1: A Theban Archive of the Reign of Ptolemy I Soter" (1939), and Thompson's "A Family Archive from Siut" (1934), set a new standard and method for the publication of demotic contracts. By painstaking compilation of family genealogies and topographical plans of streets and houses, they made the dry legal formulæ yield up a brilliant and intimate picture of the social and family life of Egyptian provincial towns in the Ptolemaic period. Vol. 2 of Glanville's "Catalogue", "The Instructions of 'Onkhsheshonqy" (1956), of which he received the first copy a few weeks before his death, broke fresh ground; in it he deciphered and translated what may well be the last great "Wisdom" book from Egypt. His deep understanding, both of Egypt and of human nature, enabled him often to interpret what might have remained dark to a more cloistered mind; while his firm critical judgment and keen historical sense controlled his imagination and ensured his accuracy.

But Glanville was by no means a one-sided scholar. During his time at the Museum, apart from editing the valuable "Studies presented to F. Ll. Griffith" (1932), he published many articles on the earlier literature and history of Egypt, and acquired a deep knowledge of Egyptian objects, for which he had always had a rare feeling. 'This became of the utmost importance at University College, London, where he was appointed a reader in 1933, and in 1935 Edwards professor of Egyptology; for his chief task there was the cataloguing of the Petrie Collection. Unfortunately, his work for it was undone by the Second World War. Meanwhile, he edited the "Legacy of Egypt" (Clarendon Press, 1942). During the War he served in the Royal Air Force, in which he reached the rank of wing commander, and was made M.B.E. and received Czechoslovak, 
Dutch and Yugoslav decorations. In 1946 he was appropriately appointed to the new chair, founded by his old master, Sir Herbert Thompson, at Cambridge, specifically for demotic and coptic studies, and was elected a professorial Fellow of King's. In the same year he was elected a Fellow of the British Academy, and recently became an honorary Fellow of his own College, Lincoln, Oxford.

At Cambridge, Glanville devoted himself not only to building up the new Department of Egyptology, its library and collections, but also served the University, his College and his Faculty in a host of functions. His courage, clear-sightedness and grasp of principle were always tempered by his warmth, his tact and his humour. Such was the trust and affection in which he was held in his College, that he became in 1954 the first Oxford man ever to be elected Provost of King's College, Cambridge. The loss of his wisdom and friendship there is as grievous as it is to his Department and students. For he was the finest type of teacher; he never spoon-fed, but worked unsparingly and sympathetically to inspire his students to make the best of their own abilities, not in their studies alone, but also in the whole of their life. His life will be an inspiration, his kindness a poignant memory, to his many friends.

\section{H. S. SмIтH}

\section{Prof. Edward Stenz}

Edward Stenz, who died after a long illness in Stockholm on February 21 at the early age of fiftysix, had many friends among meteorologists and geophysicists all over the world.

Born in Warsaw, he went to a secondary school there (the Rey Gymnasium); even as a pupil he became an enthusiastic member of the physics section under the leadership of Ziemecki, who after the War took a chair of physics at the Maria CurieSkŁodowska University of Lublin.

Stenz studied in the University of Warsaw under Kowalski, Pieńkowski, Gorczyński, Mazurkiewicz and Sierpiński; he also spent some time at the Jan Kazimierz University of Lwów, working under Arctowski. He took his Dr.Phil. degree at the Stefan Batory University of Wilno.

After graduating, Stenz became a lecturer in the Physics Department of the University of Warsaw, and was afterwards in charge of applied physics at the Technical University of Warsaw; later he was appointed director of the Observatory at Kasprowy Wierch in the Tatra Mountains. He spent the period of the Second World War in Afghanistan, being in charge of the Meteorological Office and professor in the University at Kabul. After the War he went back to Poland and was appointed professor of geophysics in the University of Warsaw. He served as president of the Geophysical Committee of the Polish Academy of Sciences, deputy director of the Institute of Geophysics, and president of the Polish Meteorological and Hydrological Society. $\mathrm{He}$ was the author of about ninety papers, covering a wide range of subjects--meteorology, terrestrial magnetism, the Sun and terrestrial radiation and gravimetric measurements; he also published several semi-popular books. All his papers were marked by a clear and attractive style as well as by a high standard of presentation. He was one of the first organizers of the meteorological service for the Polish Air Force.

Stenz was very sensitive, full of stimulating ideas, kindly disposed to others and always ready to give a helping hand to those in trouble. In the summer of 1954 he experienced a great blow : his only daughter fell to her death, while climbing in the Tatra Mountains. His own death means a great loss to Polish science and has deprived all who knew him of one of their most valued friends. JózeF MAzUR

\section{NEWS and VIEWS}

\section{Kelvin Gold Medal}

The Kelvin Gold Medal for 1956 has been awarded to Sir John Cockcroft, director of the Atomic Energy Research Establishment, Harwell. The Medal is awarded every three years to a person of any nationalicy "as a mark of distinction in engineering work of the kinds with which Lord Kelvin was especially identified", and the administration of the award is in the hands of a committee consisting of the presidents of the Institutions of Civil Engineers, Mechanical Engineers, Electrical Engineers, Naval Architects, Mining and Metallurgy, Mining Engineers, and Engineers and Shipbuilders in Scotland, and the Iron and Steel Institute.

\section{Royal Meteorological Society: Awards}

THe Royal Meteorological Society has made the following awards: Buchan Prize, founded in memory of Alexander Buchan, secretary of the Scottish Meteorological Society during 1861-1907, for the period 1951-55 has been awarded to Mr. F. H. Ludlam (Department of Meteorology, Imperial College of Science and Téchnology), for his outstanding contributions to the study of cloud physics; Hugh
Robert Mill Medal and Prize for 1956, founded in memory of Hugh Robert Mill, director of the British Rainfall Organization during 1901-19, has been awarded to Mr. J. S. Sawyer (director of the Forecasting Research Division, Meteorological Office) for his outstanding contributions to the science of meteorology, with particular reference to rainfall.

\section{Linnean Society of London}

AT the anniversary meeting of the Linnean Society of London held on May 24 the Linnean Gold Medal for 1956 was awarded to Prof. W. H. Lang, emeritus Barker professor of cryptogamic botany in the University of Manchester. The following were elected officers of the Society for the session 1956-57: President, Dr. H. Hamshaw 'Thomas; Treasurer, Sir Frederick Stern; Secretaries, Dr. H. R. Hewer (zoologỳ) and Dr. C. R. Metcalfe (botany); New Members of Council, Mr. D. Etherington, Dr. B. M. Hobby, Dr. Doris M. Kermack, Dr. John Smart and Dr. Errol I. White. Prof. I. W. Bailey, Dr. Anton Brunn, Prof. J. A. Efremov, Prof. Richard Harder, Prof. Bernhard Rensch, Prof. Karl von Frisch and Prof. $\varnothing$. Winge were elected foreign members of the Society. 